\title{
Prescribed medication use among elementary teachers: Prevalence and associated factors
}

\author{
Uso de medicamento prescrito em professores do ensino \\ fundamental: Prevalência e fatores associados
}

Diogo Henrique Constantino Coledam (https://orcid.org/0000-0001-6211-7069) ${ }^{1}$

Yara Machado da Silva (https://orcid.org/0000-0002-1969-1724) ${ }^{2}$

${ }^{1}$ Instituto Federal de Educação, Ciência e Tecnologia de São Paulo. Av. Zélia de Lima Rosa 100, Portal dos Pássaros. 18550000 Boituva SP Brasil. diogohcc@yahoo.com.br ${ }^{2}$ Universidade de Sorocaba. Sorocaba SP Brasil.

\begin{abstract}
The aims of the study were to assess the prevalence and analyze the associated factors of medication use among teachers. A cross-sectional study was carried out, involving 530 teachers from Londrina city, Paraná, Brazil. The dependent variable was prescribed medication use and the independent variables were sociodemograph$i c$, work-related, lifestyle, health disorders, and chronic diseases, all assessed through questionnaires. Prevalence of medication use was $59.1 \%$. Chronic disease was associated with all medications analyzed. Variables positively associated with medication use according to health disorder type were: Cardiometabolic (Length of employment, overweight, not current tobacco use, and $T V$ viewing); Psychological (Length of employment, common mental disorders, current tobacco use, and disability); Orthopedic (Length of employment, health insurance, overweight, musculoskeletal pain, low job support, and disability); Respiratory (TV viewing and problems related to dust or chalk powder); and Gastrointestinal (common mental disorders and physical activity [negative association]). Support for access, the appropriate use of medicines, and a reduction in medication use should consider work-related, lifestyle, and health disorders, as well as chronic diseases.
\end{abstract}

Key words Pharmaceutical Preparations, Healthy Lifestyle, Work
Resumo Os objetivos do estudo foram verificar a prevalência e analisar os fatores associados ao uso de medicamentos em professores. Estudo transversal envolvendo 530 professores da cidade de Londrina, Paraná, Brasil. As variáveis dependentes foram o uso de medicamentos prescritos e as variáveis independentes foram os aspectos sociodemográficos, relacionados ao trabalho, estilo de vida, distúrbios de saúde e doenças crônicas, todas estimadas por meio de um questionário. A prevalência do consumo de medicamento foi de 59,1\%. Doenças crônicas foram associadas a todos os medicamentos analisados. As variáveis positivamente associadas ao uso de medicamentos de acordo com o tipo de distúrbio foram: Cardiometabólico (tempo no emprego, sobrepeso, não uso atual de tabaco e uso de TV); Psicológico (tempo no emprego, transtornos mentais comuns, uso atual de tabaco e incapacidade); Ortopédico (tempo no emprego, plano de saúde, sobrepeso, dor musculoesquelética, baixo suporte no trabalho e incapacidade); Respiratório (uso de TV e problemas relacionados à poeira); Gastrointestinal (transtornos mentais comuns e atividade física [associação inversa]). O suporte ao acesso, uso apropriado e redução do uso de medicamentos devem considerar variáveis relacionadas ao trabalho, estilo de vida, distúrbios de saúde e doenças crônicas.

Palavras-chave Preparações Farmacêuticas, Estilo de Vida Saudável, Trabalho 


\section{Introduction}

Health behaviors are determinants of the four main non-communicable chronic diseases: cardiovascular, chronic respiratory, cancers, and diabetes $^{1}$. Since adults expend one third of the day working, work-related characteristics can play an important role in health ${ }^{2,3}$. Among professions associated with health impairment, teachers are highlighted due to the demands of their work, such as preparing and conducting lessons, assessing students' work performed during classes or at home, attending meetings, participating in school pedagogical planning, constantly remaining updated, and being involved in extracurricular activities. The demands become more difficult as they are generally performed with several barriers related to school and social contexts ${ }^{4,5}$.

Teachers are at risk of developing a variety of health related disorders ${ }^{6-12}$. Approximately $50 \%$ of teachers suffer from musculoskeletal symptoms in the neck, shoulders, and back ${ }^{9}$. The prevalence of respiratory disorders varies from 25.1 to $80.4 \%{ }^{6}$ and voice disorders affect $33.9 \%$ of teachers ${ }^{12}$. Regarding mental health, there is a high prevalence of high stress $(25.7 \%)^{7}$, common mental disorders $(29.7 \%)^{8}$, and burnout (8.3 to $56.6 \%)^{11}$. Furthermore, teachers also present other health risks, such as overweight $(46.7 \%)$, physical inactivity $(34.8 \%)$, low fruit and vegetable consumption (79.6\%), alcohol consumption $(21.6 \%)$, and tobacco use $(14.1 \%)^{7}$. The most commonly cited causes of health related disorders among teachers are higher length of employment, poor work conditions and environment, work overload, discipline problems, low social and job support, low self-efficacy, bad vocal use, and adverse conditions to vocal health ${ }^{4-6,8,9,11}$.

The presence of disease usually requires pharmacological management, which is effective both for preventing and treating health disorders, reducing or eliminating the symptoms of disease. The majority of epidemiological information available describes the prevalence and factors associated with medication use for the general adult population ${ }^{13-16}$. However, although there are many studies assessing health risks among elementary teachers ${ }^{6-10}$, no studies have described the medication use profile in this population.

Despite the benefits of prescribed medication in the treatment of health disorders, medicines also result in negative effects such as adverse drug reactions and hospitalizations, co-medication, dependence, and self-medication risk ${ }^{17-19}$. Furthermore, costs associated with medication use can result in catastrophic health expenditure, mainly in families with low socioeconomic sta$\operatorname{tus}^{20}$. The lack of information regarding a representative sample of elementary teachers prevents knowledge of the pattern and variables associated with higher medication consumption. These data can guide policies to provide support on access and the appropriate use of medicines with a focus on vulnerable groups. Therefore, the aims of this study were to assess the prevalence and associated factors of medication consumption among elementary teachers.

\section{Methods}

\section{Study location}

This is a cross-sectional study with a representative sample of elementary teachers from Londrina city, Paraná, Brazil, from July to December 2014. Londrina is a medium-sized city and the population was estimated at 506,701 inhabitants and a health development index $=$ 0.778 according to a census conducted in $2010^{21}$.

\section{Population and Sample}

In 2014 there were 74 municipal elementary schools in the urban area of Londrina with a total of 2,500 teachers distributed according to each region of the city: north $(32.8 \%)$, south $(20.0 \%)$, east $(20.3 \%)$, west $(22.1 \%)$, and center $(4.8 \%)$. All schools were invited to participate in the study and 63 accepted. The inclusion criteria were: a) having been a teacher of municipal schools for at least 1 year and working in an elementary school; b) not being retired or on medical leave during data collection; c) not having been work relocated (i.e., teacher working as a secretary or in administration). The sample size calculation was performed using the following parameters: $\mathrm{N}=2.500$, a $50 \%$ outcome prevalence, $5 \%$ sample error, confidence interval of $95 \%$, and design effect of 1.5, using the software OpenEpi 3.01. The minimum number of participants required was 500 stratified according to region of the city.

\section{Data collection}

The study was approved by the Ethics Committee for Research involving human beings of the State University of Londrina. The guidelines of Resolution No 466/2012 of the Brazilian National Health Council were followed. All par- 
ticipants signed an informed written consent containing the objectives, procedures, risks, and benefits of the study, as well as the researchers' contact details. Data collection was performed in five steps: 1) The project was presented to the Municipal Education Department who provided permission to conduct the study; 2) All schools that agreed to participate in the study were visited to present the study proposal and obtain authorization of the principals; 3 ) The purpose and procedures of the study were presented to teachers and data collection was scheduled randomly in schools where the teachers were enrolled; 4) Teachers completed the self-report questionnaire; 5) Data collection was performed again for teachers who were absent on the scheduled date.

\section{Variables and instruments}

The dependent variable was medication use, prescribed by a physician and consumed continuously during the previous six months. The following closed question was used to assess medication consumption: "Do you regularly use (continuously) any type of medication? Indicate only medicines used under medical prescription during the last six months". A list of medicine categories and the answer options "yes" or "no" were presented for each category. Teachers indicated the medication use for cardiometabolic (hypertension, diabetes, dyslipidemia, and cardiovascular disease), psychological (anxiety, depression, insomnia, stress, and panic syndrome), orthopedic, respiratory, gastrointestinal, nervous system, cancer and weight control related disorders. It was not performed the analysis of the association between medication used for nervous system, weight control and cancer because the low number of cases made the analysis impracticable.

The independent variables were assessed through a self-report questionnaire. Gender, age, length of employment, TV viewing, and computer use during leisure time were analyzed using open questions. The body mass index was estimated by self-report measures of height and weight. The other independent variables were assessed by the questions: Health insurance, "How do you pay for health services?", with response options "Private health insurance", "Employer's health insurance", or "I use the public health system"; Socioeconomic status was estimated according to the values proposed by the Brazilian Association of Polling Companies ${ }^{22}$; School infrastructure, "Do you consider the infrastructure of your school appropriate? (aspects that should be considered were listed: noise, temperature, lighting, cleaning, ventilation, size, and furniture)" with answer options "yes", "no", and "partially"; Voice disorders, "Do you have a frequent voice-related problem?" with answer options "yes", "no"; Problems related to chalk powder, "Do you have a frequent problem with dust or chalk powder?" with answer options "yes", "no" for each problem (nasal stuffiness, eye irritation, rhinitis, coryza, cough, skin problems); Alcohol consumption, "Usually how many times in a normal month do you consume $\geq 5$ doses of the drinks below (men) or $\geq 4$ doses (women) in less than 2 hours?" The list contained wine, beer, and distilled drinks; Tobacco use, "Have you smoked at least 100 cigarettes in your entire life?" with answer options "yes" and "no", "How often during a typical week do you smoke", "none", "1-2 days", "3-4 days", "5-6 days" and "daily"; Chronic diseases, "Has a doctor or psychologist reported that you have any of the following chronic diseases?" and answer options were "yes" and "no" for a list of categories of chronic diseases (cardiometabolic, psychological, orthopedic, respiratory, gastrointestinal, nervous system, cancer, and weight control).

Physical activity was estimated using the long form of the International Physical Activity Questionnaire (IPAQ), Brazilian version ${ }^{23}$. Section 4 was considered which includes recreational, sport, exercise, and leisure time physical activity. The cutoff used was $150 \mathrm{~min} /$ week of moderate and vigorous intensity. Musculoskeletal pain and disability were estimated using the Brazilian version of the Standardized Nordic questionnaire ${ }^{24}$. Common mental disorders were assessed by the Brazilian version of a Self Report Questionnaire ${ }^{25}$ and the cut-off adopted was 7/8. To estimate work stress, the Brazilian version of the questionnaire job stress scale ${ }^{26}$ was used, which contains demand, control, and job support dimensions. Two stress outcomes were considered: 1) Teachers who were above percentile 50 for demand and below percentile 50 for control (high demand and low control); 2) Those who were below percentile 50 on job support (low job support).

Some variables were assessed using questions elaborated to achieve the objectives of the present study. To ensure the quality of the information, the following procedures were adopted: a) The questions were developed by researchers based on the available scientific literature, study objectives, and target population; b) The questions were submitted to evaluation by a panel of 
four expert judges in the Health Sciences areas from three Universities, with experience in the validation of questionnaires, full professors of postgraduate programs and with relevant scientific production; c) The questions were modified in accordance with the suggestions of the judges; d) The questions were applied to a group of 50 participants (not included in sample of this study) over a period of seven days (test-retest) to assess the readability, clarity, comprehensiveness, and reproducibility; and e) The participants were interviewed about necessary modifications to the questions. The variables presented acceptable reproducibility (intraclass coefficient $>0.5$ for continuous variables and kappa index $>0.40$ for categorical variables).

\section{Statistical analysis}

Descriptive statistics were carried out using relative frequency. The bivariate analysis was performed using the Chi-Squared test and variables associated at $\mathrm{P}<0.20$ were included in the multivariate analysis. Logistic regression was conducted to estimate the odds ratio and confidence intervals of $95 \%$ of the associations between the independent variables and each category of medication use. In the multivariate analysis, variables were inserted in regression in different levels: Level 1 (sociodemographic and work-related characteristics), Level 2 (lifestyle and health risks), and Level 3 (disability and chronic diseases). The goodness-of-fit of each model was assessed using the Hosmer-Lemeshow test. The significance level in the final models was set at $5 \%$.

\section{Results}

A total of 595 teachers returned the questionnaires, however due to incomplete information on some variables, the final sample was composed of 530 teachers. Missing participants did not differ from those included in the final sample with regard to sex, region of the city, income, health risks, or medication consumption. Conversely, the missing sample was more prevalent in those $>40$ years of age.

Sample characteristics and the prevalence of any medication use according to independent variables among elementary school teachers are described in Table 1. The prevalence of any medication use was $59.1 \%$. Teachers with higher age and length of employment, higher socioeconomic status, overweight, common mental disorders,
Table 1. Sample characteristics and prevalence of medication use according to independent variables among elementary teachers $(n=530)$.

\begin{tabular}{|c|c|c|c|}
\hline \multirow{2}{*}{ Variables } & \multirow{2}{*}{$\begin{array}{l}\text { All } \\
(\%)\end{array}$} & \multicolumn{2}{|c|}{ Medication use } \\
\hline & & No (\%) & Yes $(\%)$ \\
\hline All & - & 40.9 & 59.1 \\
\hline Gender & & $\mathrm{P}=0.241$ & \\
\hline Male & 4.7 & 52.0 & 48.0 \\
\hline Female & 95.3 & 40.2 & 59.8 \\
\hline Age & & $\mathrm{P}<0.001$ & \\
\hline$<40$ years & 47.7 & 49.0 & 51.0 \\
\hline$\geq 40$ years & 52.3 & 33.2 & 66.8 \\
\hline Length of employment & & $\mathrm{P}<0.001$ & \\
\hline$<9$ years & 26.6 & 54.6 & 45.4 \\
\hline 10 to 19 years & 32.8 & 41.4 & 58.6 \\
\hline$>20$ years & 40.6 & 31.2 & 68.8 \\
\hline Health insurance & & $\mathrm{P}=0.799$ & \\
\hline No & 17.5 & 41.9 & 58.1 \\
\hline Yes & 82.5 & 40.5 & 59.5 \\
\hline Socioeconomic status & & $\mathrm{P}=0.022$ & \\
\hline Low & 15.8 & 50.0 & 50.0 \\
\hline Medium & 43.6 & 42.0 & 58.0 \\
\hline High & 40.6 & 35.8 & 64.2 \\
\hline School infrastructure & & $\mathrm{P}=0.082$ & \\
\hline Adequate & 21.5 & 42.7 & 57.3 \\
\hline Not adequate & 78.5 & 33.6 & 66.4 \\
\hline Overweight & & $\mathrm{P}<0.001$ & \\
\hline No & 56.4 & 50.8 & 49.2 \\
\hline Yes & 43.6 & 27.7 & 72.3 \\
\hline $\begin{array}{l}\text { Common mental } \\
\text { disorders }\end{array}$ & & $\mathrm{P}<0.001$ & \\
\hline No & 69,1 & 47.0 & 53.0 \\
\hline Yes & 30.9 & 26.8 & 73.2 \\
\hline Physical activity & & $\mathrm{P}=0.028$ & \\
\hline No & 77.9 & 38.3 & 61.7 \\
\hline Yes & 22.1 & 49.6 & 50.4 \\
\hline Musculoskeletal pain & & $\mathrm{P}<0.001$ & \\
\hline No & 16.6 & 54.5 & 45.5 \\
\hline One region & 17.9 & 51.6 & 48.4 \\
\hline Two regions & 26.2 & 41.0 & 59.0 \\
\hline$\geq$ Three regions & 39.2 & 29.8 & 70.2 \\
\hline Alcohol consumption & & $\mathrm{P}=0.687$ & \\
\hline No & 68.1 & 40.2 & 59.8 \\
\hline Yes & 31.9 & 42.0 & 58.0 \\
\hline Tobacco use & & $\mathrm{P}=0.014$ & \\
\hline Never & 87.0 & 43.2 & 56.8 \\
\hline Not current smoker & 9.6 & 25.5 & 74.5 \\
\hline Current smoker & 3.4 & 22.2 & 77.8 \\
\hline TV viewing & & $\mathrm{P}=0.104$ & \\
\hline$<2 \mathrm{~h} /$ day & 57.4 & 43.8 & 56.3 \\
\hline$\geq 2 \mathrm{~h} /$ day & 42.6 & 36.7 & 63.3 \\
\hline
\end{tabular}


Table 1. Sample characteristics and prevalence of medication use according to independent variables among elementary teachers $(n=530)$.

\begin{tabular}{|c|c|c|c|}
\hline \multirow{2}{*}{ Variables } & \multirow{2}{*}{$\begin{array}{l}\text { All } \\
(\%)\end{array}$} & \multicolumn{2}{|c|}{ Medication use } \\
\hline & & No (\%) & Yes (\%) \\
\hline Computer use & & $\mathrm{P}=0.380$ & \\
\hline$<2 \mathrm{~h} /$ day & 57.0 & 42.4 & 57.6 \\
\hline$\geq 2 \mathrm{~h} /$ day & 43.0 & 38.6 & 61.4 \\
\hline Voice disorders & & $\mathrm{P}<0.001$ & \\
\hline No & 65.1 & 46.4 & 53.6 \\
\hline Yes & 34.9 & 30.3 & 69.7 \\
\hline $\begin{array}{l}\text { Problems related to dust } \\
\text { or chalk powder }\end{array}$ & & $\mathrm{P}=0.002$ & \\
\hline No & 27.9 & 51.4 & 48.6 \\
\hline One & 33.2 & 41.5 & 58.5 \\
\hline$\geq$ Two & 38.9 & 32.5 & 67.5 \\
\hline High stress & & $\mathrm{P}=0.092$ & \\
\hline No & 71.1 & 38.5 & 61.5 \\
\hline Yes & 28.9 & 46.4 & 53.6 \\
\hline Low job support & & $\mathrm{P}=0.047$ & \\
\hline No & 59.2 & 44.3 & 55.7 \\
\hline Yes & 40.8 & 35.6 & 64.4 \\
\hline $\begin{array}{l}\text { Disability due to } \\
\text { musculoskeletal disorders }\end{array}$ & & $\mathrm{P}<0.001$ & \\
\hline No & 64.2 & 47.9 & 52.1 \\
\hline Yes & 35.8 & 27.9 & 72.1 \\
\hline Chronic disease & & $\mathrm{P}<0.001$ & \\
\hline None & 21.9 & 81.9 & 18.1 \\
\hline One & 24.0 & 57.5 & 42.5 \\
\hline Two & 21.1 & 28.6 & 71.4 \\
\hline$\geq$ Three & 33.0 & 9.1 & 90.9 \\
\hline
\end{tabular}

P refers to the chi-square test.

physical inactivity, musculoskeletal pain, tobacco use, voice disorders, problems related to dust, low job support, disability due to musculoskeletal disorders, and chronic diseases presented a higher prevalence of any medication use $(\mathrm{P}<0.05)$.

The prevalence of medication consumption for each health related disorder according to the independent variables studied is described in $\mathrm{Ta}-$ ble 2 . The prevalence ranged from $10.2 \%$ (respiratory disorders) to $27.7 \%$ (psychological disorders), while $18.1 \%$ of teachers reported the consumption of $\geq$ three medications simultaneously. Medication consumption for the nervous system, weight control, and cancer presented 3.0,2.8, and $0.4 \%$ respectively (data not shown).

Table 3 describes the multivariate association between sociodemographic and work-related characteristics and medication consumption. Length of employment increased the odds ratio of medication use for cardiometabolic, psycho- logical, orthopedic, and clustering of medication use by 1.81 to 6.37 times. The same occurred for health insurance and school infrastructure for orthopedic disorders $(\mathrm{OR}=2.42)$ and clustering of medication use $(\mathrm{OR}=1.76)$ respectively.

The multivariate analysis of the association between lifestyle and health risks and medication consumption are described in Table 4 . The variables that increased the odds ratio of cardiometabolic medication use were, overweight $(\mathrm{OR}=$ $3.59)$, currently not a smoker $(\mathrm{OR}=2.16)$, and $\mathrm{TV}$ viewing $\geq 2 \mathrm{~h}(\mathrm{OR}=1.81)$. Teachers with a common mental disorder $(\mathrm{OR}=2.57)$ and current smokers ( $\mathrm{OR}=3.81$ ) had a higher odds ratio to use medications for psychological disorders. Overweight $(\mathrm{OR}=2.09)$, musculoskeletal pain $\geq$ three regions $(\mathrm{OR}=5.03)$ and low job support $(\mathrm{OR}=1.89)$ increased the odds ratio of medication use for orthopedic disorders. TV viewing $\geq$ $2 \mathrm{~h}(\mathrm{OR}=2.06), \geq 2$ problems related to dust or chalk powder $(\mathrm{OR}=8.26)$ were positively associated with medication use for respiratory problems. Gastrointestinal medication use was higher for teachers with common mental disorders (OR $=2.47$ ) while among on those who performed physical activity the odds ratio for medication use was lower $(\mathrm{OR}=0.42)$. The clustering of medication use was more prevalent in teachers with common mental disorders $(\mathrm{OR}=3.93)$ and low support in the job $(\mathrm{OR}=1.72)$.

Teachers with disability due to musculoskeletal disorders presented higher medication consumption for psychological and orthopedic disorders and clustering medication use $(\mathrm{OR}=$ 1.67 to 7.64). The presence of chronic disease increased the likelihood of medication use for all disorders analyzed ( $\mathrm{OR}=3.79$ to 66.60$)$ (Table 5). The final models presented good fit values in the Hosmer Lemeshow goodness-of-fit test: Cardiometabolic (0.442), Psychological (0.973), Orthopedic (0.924), Respiratory (0.926), Gastrointestinal (0.308), and Clustering (0.615).

\section{Discussion}

To our knowledge, this is the first study to investigate the prevalence and associated factors of medication use among elementary teachers. In the present study the prevalence of medication consumption for psychological, cardiometabolic, gastrointestinal, orthopedic, and respiratory disorders was 27.7, 19.6, 18.5, 15.7, and 10.2\%, respectively. The prevalence was higher compared to the general population for psycholog- 
Table 2. Prevalence of prescribed medication use for cardiometabolic, psychological, orthopedic, respiratory, gastrointestinal disorders and $\geq$ three medications clustered according to independent variables studied among elementary teachers.

\begin{tabular}{|c|c|c|c|c|c|c|}
\hline \multirow{2}{*}{ Variables } & Cardiometabolic & Psychological & Orthopedic & Respiratory & Gastrointestinal & Clustering \\
\hline & $\%$ & $\%$ & $\%$ & $\%$ & $\%$ & $\%$ \\
\hline All & 19.6 & 27.7 & 15.7 & 10.2 & 18.5 & 18.1 \\
\hline Gender & $\mathrm{P}=0.584$ & $\mathrm{P}=0.020$ & $\mathrm{P}=0.982$ & $\mathrm{P}=0.278$ & $\mathrm{P}=0.157$ & $\mathrm{P}=0.053$ \\
\hline Male & 15.4 & 7.7 & 15.4 & 3.8 & 7.7 & 3.8 \\
\hline Female & 19.8 & 28.6 & 15.6 & 10.4 & 18.7 & 18.8 \\
\hline Age & $\mathrm{P}<0.001$ & $\mathrm{P}<0.001$ & $\mathrm{P}=0.002$ & $\mathrm{P}=0.395$ & $\mathrm{P}=0.778$ & $\mathrm{P}<0.001$ \\
\hline$<40$ years & 11.2 & 20.9 & 10.5 & 11.2 & 17.8 & 10.9 \\
\hline$\geq 40$ years & 27.3 & 33.8 & 20.3 & 9.0 & 18.8 & 24.8 \\
\hline Length of employment & $\mathrm{P}<0.001$ & $\mathrm{P}=0.001$ & $\mathrm{P}<0.001$ & $\mathrm{P}=0.303$ & $\mathrm{P}=0.090$ & $\mathrm{P}=<0.001$ \\
\hline$<9$ years & 6.8 & 17.8 & 4.1 & 10.3 & 15.1 & 4.8 \\
\hline 10 to 19 years & 19.4 & 26.3 & 14.4 & 12.6 & 15.5 & 16.6 \\
\hline$>20$ years & 28.4 & 35.3 & 24.3 & 7.9 & 22.8 & 28.4 \\
\hline Health insurance & $\mathrm{P}=0.218$ & $\mathrm{P}=0.039$ & $\mathrm{P}=0.006$ & $\mathrm{P}=0.334$ & $\mathrm{P}=0.311$ & $\mathrm{P}=0.037$ \\
\hline No & 14.7 & 18.9 & 6.3 & 12.6 & 14.7 & 10.5 \\
\hline Yes & 20.5 & 29.4 & 17.6 & 9.4 & 19.2 & 19.6 \\
\hline Socioeconomic status & $\mathrm{P}=0.511$ & $\mathrm{P}=0.141$ & $\mathrm{P}=0.642$ & $\mathrm{P}=0.120$ & $\mathrm{P}=0.620$ & $\mathrm{P}=0.831$ \\
\hline Low & 17.9 & 20.2 & 11.9 & 15.5 & 20.2 & 20.2 \\
\hline Medium & 18.1 & 27.4 & 14.6 & 9.7 & 16.4 & 17.3 \\
\hline High & 22.2 & 31.6 & 16.2 & 7.6 & 19.4 & 17.9 \\
\hline School infrastructure & $\mathrm{P}=0.074$ & $\mathrm{P}=0.045$ & $\mathrm{P}=0.101$ & $\mathrm{P}=0.355$ & $\mathrm{P}=0.385$ & $\mathrm{P}=0.008$ \\
\hline Adequate & 17.9 & 25.6 & 13.9 & 9.4 & 17.5 & 15.6 \\
\hline Not adequate & 25.4 & 35.1 & 20.2 & 12.3 & 21.1 & 26.3 \\
\hline Overweight & $\mathrm{P}<0.001$ & $\mathrm{P}=0.246$ & $\mathrm{P}<0.001$ & $\mathrm{P}=0.672$ & $\mathrm{P}=0.233$ & $\mathrm{P}=0.037$ \\
\hline No & 9.7 & 25.8 & 10.4 & 9.7 & 16.7 & 15.1 \\
\hline Yes & 32.5 & 30.3 & 22.5 & 10.8 & 20.8 & 22.1 \\
\hline Common mental disorders & $\mathrm{P}=0.184$ & $\mathrm{P}<0.001$ & $\mathrm{P}=0.004$ & $\mathrm{P}=0.108$ & $\mathrm{P}<0.001$ & $\mathrm{P}<0.001$ \\
\hline No & 18.1 & 21.1 & 12.6 & 8.8 & 12.1 & 10.4 \\
\hline Yes & 23.0 & 42.4 & 22.4 & 13.3 & 32.7 & 35.2 \\
\hline Physical activity & $\mathrm{P}=0.060$ & $\mathrm{P}=0.596$ & $\mathrm{P}=0.889$ & $\mathrm{P}=0.297$ & $\mathrm{P}=0.004$ & $\mathrm{P}=0.520$ \\
\hline No & 21.4 & 27.2 & 15.6 & 10.9 & 21.1 & 18.7 \\
\hline Yes & 13.6 & 29.7 & 16.1 & 7.6 & 9.3 & 16.1 \\
\hline Musculoskeletal pain & $\mathrm{P}=0.220$ & $\mathrm{P}=0.057$ & $\mathrm{P}=<0.001$ & $\mathrm{P}=0.103$ & $\mathrm{P}<0.001$ & $\mathrm{P}=0.001$ \\
\hline No & 21.6 & 17.0 & 4.5 & 3.4 & 9.1 & 10.2 \\
\hline One region & 7.2 & 25.8 & 7.2 & 9.3 & 12.4 & 7.2 \\
\hline Two regions & 23.9 & 29.0 & 13.0 & 13.0 & 15.2 & 22.5 \\
\hline$\geq$ Three regions & 21.7 & 32.4 & 26.2 & 11.6 & 27.5 & 23.7 \\
\hline Alcohol consumption & $\mathrm{P}=0.287$ & $\mathrm{P}=0.287$ & $\mathrm{P}=0.620$ & $\mathrm{P}=0.767$ & $\mathrm{P}=0.210$ & $\mathrm{P}=0.888$ \\
\hline No & 21.3 & 29.2 & 15.5 & 9.6 & 20.8 & 18.4 \\
\hline Yes & 17.3 & 24.7 & 17.3 & 10.5 & 16.0 & 17.9 \\
\hline Tobacco use & $\mathrm{P}=0.016$ & $\mathrm{P}=0.011$ & $\mathrm{P}=0.974$ & $\mathrm{P}=0.231$ & $\mathrm{P}=0.205$ & $\mathrm{P}=0.067$ \\
\hline Never & 17.7 & 25.8 & 15.4 & 10.7 & 18.6 & 16.6 \\
\hline Not current smoker & 34.7 & 34.7 & 16.3 & 4.1 & 14.3 & 28.6 \\
\hline Current smoker & 22.2 & 55.6 & 16.7 & 16.7 & 33.3 & 27.8 \\
\hline TV viewing & $\mathrm{P}=0.006$ & $\mathrm{P}=0.759$ & $\mathrm{P}=0.374$ & $\mathrm{P}=0.008$ & $\mathrm{P}=0.035$ & $\mathrm{P}=0.286$ \\
\hline$<2 \mathrm{~h} /$ day & 15.6 & 27.5 & 14.6 & 7.3 & 15.2 & 16.6 \\
\hline$\geq 2 \mathrm{~h} /$ day & 25.1 & 28.7 & 17.5 & 14.3 & 22.4 & 20.2 \\
\hline Computer use & $\mathrm{P}=0.340$ & $\mathrm{P}=0.718$ & $\mathrm{P}=0.407$ & $\mathrm{P}=0.092$ & $\mathrm{P}=0.010$ & $\mathrm{P}=0.077$ \\
\hline$<2 \mathrm{~h} /$ day & 18.3 & 27.3 & 14.7 & 8.3 & 14.7 & 15.7 \\
\hline$\geq 2 \mathrm{~h} /$ day & 21.7 & 28.8 & 17.3 & 12.8 & 23.5 & 21.7 \\
\hline
\end{tabular}


Table 2. Prevalence of prescribed medication use for cardiometabolic, psychological, orthopedic, respiratory, gastrointestinal disorders and $\geq$ three medications clustered according to independent variables studied among elementary teachers.

\begin{tabular}{|c|c|c|c|c|c|c|}
\hline \multirow{2}{*}{ Variables } & Cardiometabolic & Psychological & Orthopedic & Respiratory & Gastrointestinal & Clustering \\
\hline & $\%$ & $\%$ & $\%$ & $\%$ & $\%$ & $\%$ \\
\hline Voice disorders & $\mathrm{P}=0.272$ & $\mathrm{P}=0.087$ & $\mathrm{P}=0.106$ & $\mathrm{P}=0.016$ & $\mathrm{P}=0.016$ & $\mathrm{P}=0.026$ \\
\hline No & 18.2 & 24.9 & 13.2 & 7.9 & 15.2 & 15.0 \\
\hline Yes & 22.2 & 31.9 & 18.5 & 14.6 & 23.8 & 22.7 \\
\hline $\begin{array}{l}\text { Problems related to dust or } \\
\text { chalk powder }\end{array}$ & $\mathrm{P}=0.169$ & $\mathrm{P}=0.064$ & $\mathrm{P}=0.035$ & $\mathrm{P}<0.001$ & $\mathrm{P}=0.055$ & $\mathrm{P}=0.003$ \\
\hline No & 16.1 & 23.5 & 10.1 & 2.0 & 12.1 & 10.7 \\
\hline One & 18.0 & 24.7 & 15.3 & 6.7 & 20.2 & 16.9 \\
\hline$\geq$ Two & 23.6 & 33.5 & 20.2 & 19.2 & 21.7 & 24.6 \\
\hline High stress & $\mathrm{P}=0.967$ & $\mathrm{P}=0.643$ & $\mathrm{P}=0.476$ & $\mathrm{P}=0.081$ & $\mathrm{P}=0.131$ & $\mathrm{P}=0.258$ \\
\hline No & 19.6 & 28.3 & 16.4 & 11.6 & 20.1 & 19.3 \\
\hline Yes & 19.7 & 26.3 & 13.9 & 6.6 & 14.5 & 15.1 \\
\hline Low job support & $\mathrm{P}=0.537$ & $\mathrm{P}=0.008$ & $\mathrm{P}=0.002$ & $\mathrm{P}=0.023$ & $\mathrm{P}=0.128$ & $\mathrm{P}=0.001$ \\
\hline No & 20.5 & 23.4 & 11.6 & 7.7 & 16.3 & 13.5 \\
\hline Yes & 18.3 & 33.9 & 21.6 & 13.8 & 21.6 & 24.8 \\
\hline $\begin{array}{l}\text { Disability due to } \\
\text { musculoskeletal disorders }\end{array}$ & $\mathrm{P}=0.089$ & $\mathrm{P}<0.001$ & $\mathrm{P}<0.001$ & $\mathrm{P}=0.092$ & $\mathrm{P}=0.022$ & $\mathrm{P}<0.001$ \\
\hline No & 17.3 & 21.1 & 5.4 & 8.6 & 15.8 & 11.0 \\
\hline Yes & 23.4 & 38.3 & 34.0 & 13.3 & 23.9 & 30.3 \\
\hline Chronic disease & $\mathrm{P}<0.001$ & $\mathrm{P}<0.001$ & $\mathrm{P}<0.001$ & $\mathrm{P}<0.001$ & $\mathrm{P}<0.001$ & $\mathrm{P}<0.001$ \\
\hline None & 2.6 & 5.2 & 2.6 & 0.9 & 4.3 & 0.9 \\
\hline One & 13.0 & 10.7 & 9.9 & 6.1 & 6.9 & 2.3 \\
\hline Two & 15.3 & 28.8 & 12.6 & 9.0 & 18.0 & 7.2 \\
\hline$\geq$ Three & 38.7 & 54.9 & 30.8 & 20.2 & 37.0 & 48.6 \\
\hline
\end{tabular}

ical $(5.5 \text { to } 18.4 \%)^{15,16,27,28}$, gastrointestinal $(7.3$ to $12.8 \%)^{16,29,30}$, orthopedic $(5.7 \text { to } 9.1 \%)^{15,16,30}$, and respiratory medication $(1.9 \text { to } 4.1 \%)^{15,16,29,30}$. One study showed a higher prevalence of medication use for the alimentary tract and metabolism $(19.1 \%)^{15}$, however unlike the present study, this category included anti-obesity products and medication for diabetes.

The higher prevalence of medication use compared to the general population for psychological, gastrointestinal, orthopedic, and respiratory disorders can be explained by risks associated with the teaching profession. It has been extensively described that teachers are affected by behavioral risks, poor physical health, musculoskeletal pain, mental disorders, high stress, and voice and respiratory disorders ${ }^{6-12}$ and the data from the present study suggest that this could result in high medication use to treat these health disorders. Psychotropic medication was the most commonly used in the sample studied. This corroborates with the results of a study that demon- strated that teachers are the professionals with the highest number of medical sick leave days due to mental disorders among public servants ${ }^{31}$. It is probable they are more exposed to mental disorders compared to other professionals. Another aspect that reinforces this statement is that length of employment was positively associated with four of the six dependent variables analyzed in the present study. Teachers with a longer length of employment are exposed to profession conditions and health risks for a longer time and for this reason, have less quality of life compared to their peers with a low length of employment ${ }^{32}$.

Previous studies demonstrated that sociodemographic variables such as sex and age are related to medication use in the general population $^{13,15,16,27-30}$, however, the present study reported contrary results. With regard to sex, the sample analyzed was composed of teachers and there is no evidence describing that work conditions affects the health of men and women in different ways. Similarly, age was not related to any type 
Table 3. Association between sociodemographic and work-related characteristics and prescribed medication use for cardiometabolic, psychological, orthopedic, respiratory, gastrointestinal disorders and $\geq$ three medications clustered among elementary teachers.

\begin{tabular}{|c|c|c|c|c|c|c|}
\hline \multirow{2}{*}{ Variables } & Cardiometabolic & Psychological & Orthopedic & Respiratory & Gastrointestinal & Clustering \\
\hline & OR (95\%CI) & OR (95\%CI) & OR (95\%CI) & OR $(95 \% \mathrm{CI})$ & OR (95\%CI) & OR (95\%CI) \\
\hline \multicolumn{7}{|l|}{ Gender } \\
\hline Male & - & Reference & Reference & Reference & Reference & Reference \\
\hline Female & - & $3.85(0.88-16.90)$ & - & - & $2.48(0.57-10.78)$ & $3.70(0.47-28.66)$ \\
\hline \multicolumn{7}{|l|}{ Age } \\
\hline$<40$ years & Reference & Reference & Reference & Reference & Reference & Reference \\
\hline$\geq 40$ years & $1.72(0.94-3.13)$ & $1.32(0.77-2.25)$ & $0.93(0.48-1.82)$ & - & - & $1.33(0.70-2.53)$ \\
\hline \multicolumn{7}{|l|}{$\begin{array}{l}\text { Length of } \\
\text { employment }\end{array}$} \\
\hline$<9$ years & Reference & Reference & Reference & Reference & Reference & Reference \\
\hline 10 to 19 years & $3.28(1.49-7.19)$ & $1.47(0.83-2.57)$ & $3.69(1.44-9.42)$ & - & $1.00(0.54-1.86)$ & $3.34(1.39-8.03)$ \\
\hline$>20$ years & $3.65(1.56-8.52)$ & $1.81(1.06-3.09)$ & $6.37(2.31-17.52)$ & - & $1.44(0.82-2.55)$ & $5.00(1.94-12.84)$ \\
\hline \multicolumn{7}{|l|}{ Health insurance } \\
\hline No & - & Reference & Reference & Reference & Reference & Reference \\
\hline Yes & - & $1.42(0.78-2.56)$ & $2.42(1.02-5.97)$ & - & - & $1.42(0.68-2.95)$ \\
\hline \multicolumn{7}{|l|}{$\begin{array}{l}\text { Socioeconomic } \\
\text { status }\end{array}$} \\
\hline Low & - & Reference & Reference & Reference & Reference & Reference \\
\hline Medium & - & $1.37(0.72-2.61)$ & - & $0.60(0.28-1.25)$ & - & - \\
\hline High & - & $1.69(0.88-3.25)$ & - & $0.45(0.20-1.01)$ & - & - \\
\hline \multicolumn{7}{|l|}{$\begin{array}{l}\text { School } \\
\text { infrastructure }\end{array}$} \\
\hline Adequate & Reference & Reference & Reference & Reference & Reference & Reference \\
\hline Not adequate & $1.49(0.89-2.49)$ & $1.56(0.97-2.50)$ & $1.44(0.82-2.54)$ & - & - & $1.76(1.03-2.98)$ \\
\hline
\end{tabular}

Clustering: $\geq 3$ medications simultaneously. OR $(95 \% \mathrm{CI})=$ Adjusted odds ratio and confidence interval of $95 \%$. The models were adjusted for variables that presented $\mathrm{P}<0.20$ in the Chi-Squared test. Bold denotes significant associations $(\mathrm{P}<0.05)$.

of medication use in the adjusted model. Length of employment was inserted in the same block as the age variable, which indicates that work can affect medication use independent of age.

As expected, the number of chronic diseases diagnosed was positively associated with all types of medication use analyzed. Chronic non-communicable diseases are the main causes of mortality, disability, and health costs in the general population ${ }^{33}$. Since chronic diseases are treatable but irreversible, intervention programs aimed at decreasing medication use among teachers should focus on preventing health risks associated with the development of chronic diseases ${ }^{33}$.

Musculoskeletal pain ( $\geq$ three regions of body), overweight, health insurance, and low job support were associated with medication use for orthopedic disorders. Although it was expected that musculoskeletal pain would be associated with medication use for orthopedic disorders, only teachers with pain in $\geq$ three regions of the body presented higher medication use. Multisite pain presented a significant association with medication use as it can reflect in higher discomfort and limitations compared to isolated pain. This could possibly also explain the association found for low job support, since it is related to multisite pain among workers ${ }^{34}$. Furthermore, overweight was associated with medication use due to an increased risk of orthopedic disorders resulting in higher body load and a pro-inflammatory state ${ }^{35}$. Similarly, health insurance was associated with medication use for orthopedic disorders. However, this variable may not be considered a risk for medication use. Orthopedic disorders require expensive procedures (i.e., medical imaging) and for this reason, teachers who have health insurance probably have greater opportunity for diagnosis, treatment, and monitoring of orthopedic diseases.

Disability due to musculoskeletal disorders predicted medication use for musculoskeletal 
Table 4. Association between lifestyle and health risks and prescribed medication use for cardiometabolic, psychological, orthopedic, respiratory, gastrointestinal disorders and $\geq$ three medications clustered among elementary teachers.

\begin{tabular}{|c|c|c|c|c|c|c|}
\hline \multirow{2}{*}{ Variables } & Cardiometabolic & Psychological & Orthopedic & Respiratory & Gastrointestinal & Clustering \\
\hline & OR $(95 \% C I)$ & OR $(95 \% C I)$ & OR $(95 \% C I)$ & OR $(95 \% \mathrm{CI})$ & OR (95\%CI) & OR $(95 \% \mathrm{CI})$ \\
\hline \multicolumn{7}{|l|}{ Overweight } \\
\hline No & Reference & - & Reference & Reference & Reference & Reference \\
\hline Yes & 3.59 (2.15-5.99) & - & $2.09(1.21-3.60)$ & - & - & $1.21(0.71-2.07)$ \\
\hline
\end{tabular}

\begin{tabular}{|c|c|c|c|c|c|c|}
\hline No & Reference & Reference & Reference & Reference & Reference & Reference \\
\hline Yes & $1.01(0.59-1.74)$ & $2.57(1.61-4.09)$ & $1.16(0.65-2.06)$ & $0.86(0.45-1.64)$ & $2.47(1.48-4.13)$ & $3.93(2.22-6.93)$ \\
\hline \multicolumn{7}{|l|}{ Physical activity } \\
\hline No & Reference & Reference & Reference & Reference & Reference & Reference \\
\hline Yes & $0.83(0.43-1.60)$ & - & - & - & $0.42(0.20-0.88)$ & \\
\hline \multicolumn{7}{|c|}{ Musculoskeletal pain } \\
\hline No & - & Reference & Reference & Reference & Reference & Reference \\
\hline One region & - & $1.24(0.56-2.74)$ & $1.39(0.37-5.20)$ & $2.08(0.51-8.42)$ & $1.03(0.36-2.89)$ & $0.34(0.10-1.11)$ \\
\hline Two regions & - & $1.27(0.61-2.66)$ & $2.06(0.63-6.73)$ & $2.70(0.72-10.07)$ & $1.32(0.51-3.45)$ & $1.23(0.48-3.12)$ \\
\hline$\geq$ Three regions & - & $1.44(0.71-2.92)$ & $5.03(1.64-15.39)$ & $2.00(0.54-7.32)$ & $2.22(0.90-5.47)$ & $1.18(0.48-2.91)$ \\
\hline
\end{tabular}

Alcohol consumption

\begin{tabular}{|c|c|c|c|c|c|c|}
\hline No & - & Reference & Reference & Reference & Reference & Reference \\
\hline Yes & - & - & - & - & - & - \\
\hline \multicolumn{7}{|l|}{ Tobacco use } \\
\hline Never & Reference & Reference & Reference & Reference & Reference & Reference \\
\hline $\begin{array}{l}\text { Not current } \\
\text { smoker }\end{array}$ & $2.16(1.03-4.54)$ & $1.16(0.57-2.38)$ & - & - & - & $1.87(0.81-4.27)$ \\
\hline Current smoker & $1.05(0.31-3.53)$ & $3.81(1.32-10,96)$ & - & - & - & $1.16(0.33-4.11)$ \\
\hline \multicolumn{7}{|l|}{ TV viewing } \\
\hline$<2 \mathrm{~h} /$ day & Reference & Reference & Reference & Reference & Reference & Reference \\
\hline$\geq 2 \mathrm{~h} /$ day & $1.81(1.11-2.96)$ & - & - & $2.06(1.11-3.83)$ & $1.60(0.97-2.61)$ & - \\
\hline \multicolumn{7}{|l|}{ Computer use } \\
\hline$<2 \mathrm{~h} /$ day & Reference & Reference & Reference & Reference & Reference & Reference \\
\hline$\geq 2 \mathrm{~h} /$ day & - & - & - & $1.32(0.71-2.44)$ & $1.60(0.98-2.61)$ & $1.71(0.99-2.91)$ \\
\hline \multicolumn{7}{|l|}{ Voice disorders } \\
\hline No & Reference & Reference & Reference & Reference & Reference & Reference \\
\hline Yes & - & $1.14(0.71-1.82)$ & $1.06(0.60-1.87)$ & $1.36(0.74-2.50)$ & $1.42(0.85-2.37)$ & $1.15(0.65-2.02)$ \\
\hline
\end{tabular}

Problems related to dust or chalk powder

No

One

Reference

Reference

Reference

Reference

Reference

Reference

$\geq$ Two

$1.51(0.68-3.34)$

4) $2.97(0.80-10.98)$

$1.38(0.68-2.79)$

9) $1.29(0.60-2.81)$

High stress

No

Yes

Reference

Reference

Reference

$\begin{array}{rr}\text { Reference } & \text { Reference } \\ -\quad 0.68(0.31-1.47) & 1.02(0.57-1.82)\end{array}$

Reference

Low job support No $0.05)$. 
and psychological disorders. Disability is a severe condition of the musculoskeletal system that initiates with musculoskeletal pain ${ }^{36}$. Due to the severity of the clinical condition, patients with musculoskeletal disability are generally affected, in a higher proportion compared to the general population, by psychological disorders including common mental disorders, major depression, anxiety, and substance and personality disorders ${ }^{37}$. The treatment of psychological disorders can require pharmacological use $\mathrm{e}^{38}$, which results in higher psychotropic consumption by those affected by mental disorders, as described in the present study. Similarly, tobacco use was also positively associated with psychotropic consumption. Epidemiological studies have demonstrated that tobacco use is associated with subsequent depression or anxiety, and vice-versa ${ }^{39}$. Although the direction of the association it is not clear $^{39}$, teachers who use tobacco are at risk of consuming psychotropic medication, probably to treat mental disorders.

It has been described that alcohol consumption, overweight, tobacco use, and physical activity are determinants of non communicable chronic diseases ${ }^{40}$. In the present study, overweight was associated with medication use for cardiometabolic disorders, which possibly explains the higher risk of teachers with this characteristic having cardiometabolic disorders. Only not current smokers presented a higher odds ratio to use cardiometabolic medication, because they were smokers in the past. The same occurred for sedentary behavior and although this is not included among the main health-risks related to non communicable chronic diseases ${ }^{33,40}$, evidence from a systematic review demonstrated that sedentary behaviour is associated with the incidence of cardiovascular disease, cancer, and type $2 \mathrm{di}$ abetes diseases in adults ${ }^{41}$. Conversely, physical activity was not associated with cardiometabolic medication use in the present study. The association between sedentary behavior and physical activity with health among adults has been widely studied. There is evidence that time spent sedentary is strongly associated with cardiometabolic health and is a better indicator than physical activity among adults with a high risk of type 2 diabetes mellitus ${ }^{42}$. However, this is not a consensus in the literature and additional information has described an independent association between sedentary behavior and physical activity with cardiometabolic health in adults ${ }^{43}$. Furthermore, data regarding the association between physical activity and medication use 
in the general population is controversial ${ }^{16,28,29}$ and although physical activity can prevent risk factors and chronic diseases among the general population, the results of the present study indicate that it is not associated with cardiometabolic medication use among elementary teachers.

Medication use for gastrointestinal disorders was higher for teachers with common mental disorders and lower for those who were physically active. Gastrointestinal disorders are somatic symptoms commonly presented by people with common mental disorders. In addition, the instrument used to assess common mental disorders in the present study contained two questions regarding gastrointestinal disorders: poor digestion and unpleasant sensations in the stomach $^{25}$. Another aspect that could explain the association is that psychopharmacological treatment is also used to treat gastrointestinal disorders $^{44}$. With regard to physical activity, it is a primary treatment for irritable bowel syndrome and should be considered before pharmacological treatment ${ }^{44}$.

Teachers who had two or more health problems related to dust and chalk powder presented higher medication use for respiratory disorders compared to those who did not have these health problems. Teachers are exposed daily to respiratory health risks such as dampness, pests, dust, and poor indoor-outdoor air exchange, work related risks associated with respiratory disorders ${ }^{6}$. In Brazil, chalk is usually used to write on the blackboard and this characteristic increases dust accumulation in classrooms, and the present study described that it can increase medication use for respiratory disorders. Although sedentary behavior is associated with chronic diseases such as chronic obstructive pulmonary disease due to cardiorespiratory limitation ${ }^{45}$, problems related to dust or chalk powder analyzed in the present study did not include chronic diseases, however all analyses were adjusted for this variable. The association between TV viewing and medication use for respiratory disorders could be due to the preferences for sedentary activities in people with disorders that require pharmacological treatment for respiratory disorders.

It is well known that work condition can impair teachers' health ${ }^{6,9,11}$. Curiously, in the present study infrastructure of schools and low job support were associated with consumption of three or more medications but not with isolated specific medication use. Brazilian teachers commonly deal with an inadequate work environment related to cleaning, lighting, furniture, noise, tem- perature, relationships with co-workers and superiors, social relevance of work, motivation, and remuneration ${ }^{46}$. Generally, work characteristics are not isolated and can affect different aspects of health and possibly result in concomitant medication use. Similarly, teachers with low job support presented higher clustered medication use. In the present study two indicators of stress were analyzed: High demand/low control of work and low support on job. Information specifically describing the effects of dimensions of stress on health is scarce. Stress is commonly studied as a unique dimension and the literature describes the effects of stress on psychological, physiological, psychosomatic, immune, cardiovascular, and metabolic systems, as well as on disease onset ${ }^{47}$. The association of low job support and clustered medication use found in the present study could be a characteristic of teachers' work.

Generalization of the present results to elementary school teachers from other Brazilian regions can be made since work conditions and health related disorders associated with the teaching profession are similar independent of location. Furthermore, educational systems are guided by federal guidelines which are similar across regions, despite adaptations due to local characteristics being common. However, the results should not be extrapolated to the general population, since health related disorders of the teaching profession may not occur in the same magnitude ${ }^{48}$ and as a consequence, medication consumption could be different.

Some limitations of the present study should be considered when interpreting the results. Recall is a bias inherent when using self-report questionnaires and commonly the measures of validity and reproducibility are not perfect. High errors of measurement affect analysis since they attenuate the magnitude of associations and decrease the power of studies ${ }^{49}$. Some methodological procedures (steps of development of questions described in the methods) were conducted to ensure information quality and minimize this limitation. Moreover, as an inclusion criterion of the study, values $>0.40$ were used for the kappa statistic in the test-retest for categorical variables, an agreement that can be classified as moderate ${ }^{50}$ and commonly adopted in epidemiological studies $^{49}$. A cross-sectional design was adopted and although the analyses were conducted based on conceptual frameworks, it was not possible to confirm causality of the associations described. Medication use was estimated only for medication used under prescription. This limitation 
could underestimate the prevalence of medication use as self medication is a common practice among adults ${ }^{19}$. Another limitation is that prescribed medication suspended prior to data collection was not considered. Furthermore, medication was estimated according to health disorders and there is no information regarding the quantity or active principle of the medicines reported by teachers. Finally, another limitation is that the study did not control for the healthy worker effect since all teachers in the sample were working at the time of data collection. If teachers on sick leave had been included in the analysis, it is probable that the prevalence of medication consumption could be higher.

\section{Collaborations}

DHC Coledam participated in the conception and design of the study, acquisition of data, analysis and interpretation of data, drafting the article and approve the final version to be submitted. YM Silva participated in the acquisition of data, analysis and interpretation of data, revised it critically and approved the final version of the manuscript.

\section{Conclusions}

A prevalence of medication use higher than 10\% was found for treatment of respiratory, orthopedic, gastrointestinal, cardiometabolic, and psychological disorders. The consumption of at least one medicine was present in $59.1 \%$ of the sample and the prevalence of a combination of three or more was present in $18.1 \%$. Programs aimed at supporting access, appropriate use, and reduction in medication use among elementary teachers should be directed at prevention of chronic diseases, disability, common mental disorders, musculoskeletal pain, lifestyle risks, low job support, schools with inadequate infrastructure, and teachers with a longer length of employment. 


\section{References}

1. World Health Organization (WHO). Global status report on noncommunicable diseases 2010. Geneva: WHO; 2011.

2. Neylon A, Canniffe C, Anand S, Kreatsoulas C, Blake GJ, Sugrue D, McGorrian C. A global perspective on psychosocial risk factors for cardiovascular disease. Prog Cardiovasc Dis 2013; 55(6):574-581.

3. Salvagioni DAJ, Melanda FN, Mesas AE, González AD, Gabani FL, Andrade SM. Physical, psychological and occupational consequences of job burnout: A systematic review of prospective studies. PloS One 2017; 12(10):e0185781.

4. Skaalvik EM, Skaalvik S. Teacher job satisfaction and motivation to leave the teaching profession: Relations with school context, feeling of belonging, and emotional exhaustion. Teach Teach Educ 2011; 27(6):10291038.

5. McGill TM, Self-Brown SR, Lai BS, Cowart-Osborne M, Tiwari A, LeBlanc M, Kelley ML. Effects of exposure to community violence and family violence on school functioning problems among urban youth: The potential mediating role of posttraumatic stress symptoms. Front Public Health 2014; 2:8.

6. Claudio L, Rivera GA, Ramirez OF. Association Between Markers of Classroom Environmental Conditions and Teachers' Respiratory Health. J Sch Health 2016; 86(6):444-451.

7. Santos MN, Marques AC. Condições de saúde, estilo de vida e características de trabalho de professores de uma cidade do sul do Brasil. Cien Saude Colet 2013; 18(3):837-846.

8. Carlotto MS, Câmara SG. Prevalence and risk factors of common mental disorders among teachers. Rev Psicol Trabajo Organ 2015; 31(3):201-206.

9. Coledam DHC, Pires-Júnior R, Ribeiro EAG, Oliveira AR. Factors associated with musculoskeletal disorders and disability in elementary teachers: A cross-sectional study. J Bodyw Mov Ther 2019; 23(3):658-665.

10. Silva LG, Silva MCS. Condições de trabalho e saúde de professores pré-escolares da rede pública de ensino de Pelotas, RS, Brasil. Cien Saude Colet 2013; 18(11):3137-3146.

11. Batista JBV, Carlotto MS, Coutinho AS, Augusto LGS. Prevalência da Síndrome de Burnout e fatores sociodemográficos e laborais em professores de escolas municipais da cidade de João Pessoa, PB. Rev Bras Epidemiol 2010; 13(3):502-512.

12. Rocha LM, Behlau M, Souza LDM. Behavioral Dysphonia and Depression in Elementary School Teachers. J Voice 2015; 29(6):712-717.

13. Bertoldi AD, Dal Pizzol TS, Ramos LR, Mengue SS, Luiza VL, Tavares NUL, Farias MR, Oliveira MA, Arrais PSD. Perfil sociodemográfico dos usuários de medicamentos no Brasil: resultados da PNAUM 2014. Rev Saude Publica 2016; 50(Supl. 2):5s.

14. Gomes VP, Silva MT, Galvão TF. Prevalência do consumo de medicamentos em adultos brasileiros: uma revisão sistemática. Cien Saude Colet 2017; 22(8):2615-2626.

15. Galvao TF, Silva MT, Gross R, Pereira MG. Medication use in adults living in Brasilia, Brazil: a cross-sectional, population-based study. Pharmacoepidemil Drug Saf 2014; 23(5):507-514
16. Costa KS, Barros MBDA, Francisco PMSB, César CLG, Goldbaum M, Carandina L. Utilização de medicamentos e fatores associados: um estudo de base populacional no Município de Campinas, São Paulo, Brasil. Cad Saude Publica 2011; 27(4):649-658.

17. Campbell G, Nielsen S, Larance B, Bruno R, Mattick R, Hall W, Lintzeris N, Cohen M, Smith K, Degenhardt L. Pharmaceutical opioid use and dependence among people living with chronic pain: associations observed within the pain and opioids in treatment (POINT) cohort. Pain Med 2015; 16(9):1745-1758.

18. Bouvy JC, Bruin ML, Koopmanschap MA. Epidemiology of adverse drug reactions in Europe: a review of recent observational studies. Drug Saf 2015; 38(5):437-453.

19. Pons ES, Knauth DR, Vigo Á, Mengue SS, PNAUM Research Group. Predisposing factors to the practice of self-medication in Brazil: Results from the national survey on access, use and promotion of rational use of medicines (PNAUM). PloS One 2017; 12(12):e0189098.

20. Boing AC, Bertoldi AD, Barros AJD, Posenato LG, Peres KG. Desigualdade socioeconômica nos gastos catastróficos em saúde no Brasil. Rev Saude Publica 2014; 48(4):632-641.

21. Instituto Brasileiro de Geografia e Estatística (IBGE). Cidades 2018 [Internet]. [cited 2018 Mar 22]. Available from: https://cidades.ibge.gov.br/brasil/pr/londrina/panorama

22. Associação Brasileira de Empresas de Pesquisa. Critério de classificação econômica Brasil 2012 [Internet]. [cited 2018 Mar 22]. Available from: http:// www.abep.org/criterio-brasil

23. Matsudo S, Araújo T, Marsudo V, Andrade D, Andrade E, Oliveira LC, Braggion G. Questionário internacional de atividade física (IPAQ): estudo de validade e reprodutibilidade no Brasil. Rev Bras Ativ Fís Saúde 2001; 6(2):5-18.

24. Barros ENC, Alexandre NMC. Cross-cultural adaptation of the Nordic musculoskeletal questionnaire. Int Nurs Rev 2003; 50(2):101-108.

25. Santos KOB, Araújo TM, Oliveira NF. Estrutura fatorial e consistência interna do Self-Reporting Questionnaire (SRQ-20) em população urbana. Cad Saude Publica 2009; 25(1):214-222.

26. Alves MGDM, Chor D, Faerstein E, Lopes CDS, Werneck GL. Versão resumida da "job stress scale": adaptação para o português. Rev Saude Publica 2004; 38(2):164-171.

27. Quintana MI, Andreoli SB, Peluffo MP, Ribeiro WS, Feijo MM, Bressan RA, Coutinho ESF, Mari JJ. Psychotropic Drug Use in São Paulo, Brazil - An Epidemiological Survey. PLoS One 2015; 10(8):e0135059.

28. Prado MAMBD, Francisco PMSB, Barros MBDA. Uso de medicamentos psicotrópicos em adultos e idosos residentes em Campinas, São Paulo: um estudo transversal de base populacional. Epidemiol Serv Saude 2017; 26(4):747-758

29. Bertoldi AD, Barros AJ, Hallal PC, Lima RC. Utilização de medicamentos em adultos: prevalência e determinantes individuais. Rev Saude Publica 2004; 38(2):228-238. 
30. Vosgerau MZDS, Soares DA, Souza RKTD, Matsuo T, Carvalho GDS. Consumo de medicamentos entre adultos na área de abrangência de uma Unidade de Saúde da Família. Cien Saude Colet 2011; 16(S1):16291638.

31. Silva EBDF, Tomé LADO, Costa TDJGD, Santana MDCCP. Transtornos mentais e comportamentais: perfil dos afastamentos de servidores públicos estaduais em Alagoas, 2009. Epidemiol Serv Saude 2012; 21(3):505-514.

32. Pereira ÉF, Teixeira CS, Lopes ADS. Qualidade de vida de professores de educação básica do município de Florianópolis, SC, Brasil. Cien Saude Colet 2013; 18(7):1963-1970.

33. Beaglehole R, Bonita R, Horton R, Adams C, Alleyne G, Asaria, P, Baugh V, Bekedam H, Billo N, Casswell S, Cecchini M, Colagiuri R, Colagiuri S, Collins T, Ebrahim S, Engelgau M, Galea G, Gaziano T, Geneau R, Haines A, Hospedales J, Jha P, Keeling A, Leeder S, Lincoln P, McKee M, Mackay J, Magnusson R, Moodie R, Mwatsama M, Nishtar S, Norrving B, Patterson D, Piot P, Ralston J, Rani M, Reddy KS, Sassi F, Sheron N, Stuckler D, Suh I, Torode J, Varghese C, Watt J, Lancet NCD Action Group, NCD Alliance. Priority actions for the non-communicable disease crisis. Lancet 2011; 377(9775):1438-1447.

34. Fernandes RDCP, Pataro SMS, Carvalho RB, Burdorf A. The concurrence of musculoskeletal pain and associated work-related factors: a cross sectional study. BMC Public Health 2016; 16(1):628.

35. Parratte S, Pesenti S, Argenson JN. Obesity in orthopedics and trauma surgery. Orthop Traumatol Surg Res 2014; 100(1):S91-S97.

36. Haukka E, Kaila-Kangas L, Ojajärvi A, Saastamoinen P, Holtermann A, Jørgensen MB, Karppinen J, Heliövaara M, Leino-Arjas P. Multisite musculoskeletal pain predicts medically certified disability retirement among Finns. Eur J Pain 2015; 19(8):1119-1128.

37. Dersh J, Gatchel RJ, Mayer T, Polatin P, Temple OR. Prevalence of psychiatric disorders in patients with chronic disabling occupational spinal disorders. Spine 2006; 31(10):1156-1162.

38. Schumann G, Binder EB, Holte A, Kloet ER, Oedegaard KJ, Robbins TW, Walker-Tilley TR, Bitter I, Brown VJ, Buitelaar J, Ciccocioppo R, Cools R, Escera C, Fleischhacker W, Flor H, Frith CD, Heinz A, Johnsen E, Kirschbaum C, Klingberg T, Lesch K-P, Lewis S, Maier W, Mann K, Martinot J-L, Meyer-Lindenberg A, Müller CP, Müller WE, Nutt DJ, Persico A, Perugi G, Pessiglione M, Preuss UW, Roiser JP, Rossini PM, Rybakowski JK, Sandi C, Stephan KE, Undurraga J, Vieta E, van der Wee N, Wykes T, Haro JM, Wittchen NU. Stratified medicine for mental disorders. Eur Neuropsychopharmacol 2014; 24(1):5-50.

39. Fluharty M, Taylor AE, Grabski M, Munafò MR. The association of cigarette smoking with depression and anxiety: a systematic review. Nicotine Tob Res 2017; 19(1):3-13.

40. Schmidt MI, Duncan BB, Silva GA, Menezes AM, Monteiro CA, Barreto SM, Chor D, Menezes PR. Chronic non-communicable diseases in Brazil: burden and current challenges. Lancet 2011; 377(9781):1949-1961.
41. Biswas A, Oh PI, Faulkner GE, Bajaj RR, Silver MA, Mitchell MS, Alter DA. Sedentary time and its association with risk for disease incidence, mortality, and hospitalization in adults: a systematic review and meta-analysis. Ann Intern Med 2015; 162(2):123-132.

42. Henson J, Yates T, Biddle SJ, Edwardson CL, Khunti K, Wilmot EG, Gray LJ, Gorely T, Nimmo MA, Davies MJ. Associations of objectively measured sedentary behaviour and physical activity with markers of cardiometabolic health. Diabetologia 2013; 56(5):10121020.

43. Ekblom Ö, Ekblom-Bak E, Rosengren A, Hallsten M, Bergström G, Börjesson M. Cardiorespiratory fitness, sedentary behaviour and physical activity are independently associated with the metabolic syndrome, results from the SCAPIS pilot study. PLoS One 2015; 10(6): 0131586.

44. Grundmann O, Yoon SL. Irritable bowel syndrome: epidemiology, diagnosis and treatment: an update for health-care practitioners. J Gastroenterol Hepatol 2010; 25(4):691-699.

45. Hill K, Gardiner PA, Cavalheri V, Jenkins SC, Healy GN. Physical activity and sedentary behaviour: applying lessons to chronic obstructive pulmonary disease. Intern Med J 2015; 45(5):474-482.

46. Pereira ÉF, Teixeira CS, Andrade RD, Bleyer FT, Lopes ADS. Associação entre o perfil de ambiente e condições de trabalho com a percepção de saúde e qualidade de vida em professores de educação básica. Cad Saude Colet 2014; 22(2):113-119.

47. Ganster DC, Rosen CC. Work stress and employee health: A multidisciplinary review. J Manage 2013; 39(5):1085-1122.

48. Titheradge D, Hayes R, Longdon B, Allen K, Price A, Hansford L, Nye E, Ukoumunne OC, Byford S, Norwich B, Fletcher M, Logan S, Ford T. Psychological distress among primary school teachers: a comparison with clinical and population samples. Public Health 2019; 166:53-56.

49. Masson LF, McNeill G, Tomany JO, Simpson JA, Peace HS, Wei L, Grubb DA, Bolton-Smith C. Statistical approaches for assessing the relative validity of a food-frequency questionnaire: use of correlation coefficients and the kappa statistic. Public Health Nutr 2003; 6(3):313-321.

50. Landis JR, Koch GG. The Measurement of Observer Agreement for Categorical Data. Biometrics 1977; 33:159-174.

Article submitted 24/03/2018

Approved 15/04/2019

Final version submitted 17/04/2019 